\title{
Hepatobiliary Secretion Kinetics of Conjugated Bile Acids Measured in Pigs by ${ }^{11} \mathrm{C}$-Cholylsarcosine PET
}

\author{
Michael Sørensen ${ }^{1,2}$, Ole Lajord Munk ${ }^{1}$, Nikolaj W. Ørntoft ${ }^{1}$, Kim Frisch ${ }^{1}$, Kasper Jarlhelt Andersen ${ }^{3}$, \\ Frank Viborg Mortensen ${ }^{3}$, Aage Kristian Olsen Alstrup ${ }^{1}$, Peter Ott ${ }^{2}$, Alan F. Hofmann ${ }^{4}$, and Susanne Keiding ${ }^{1,2}$ \\ ${ }^{I}$ Department of Nuclear Medicine and PET Centre, Aarhus University Hospital, Aarhus, Denmark; ${ }^{2}$ Department of Hepatology \\ and Gastroenterology, Aarhus University Hospital, Aarhus, Denmark; ${ }^{3}$ Department of Surgical Gastroenterology, Aarhus University \\ Hospital, Aarhus, Denmark; and ${ }^{4}$ Department of Medicine, University of California San Diego, San Diego, California
}

The aim of this study was to develop a method for the quantification of hepatobiliary uptake and secretion of conjugated bile acids with PET and the ${ }^{11} \mathrm{C}$-labeled conjugated bile acid analog $\left[N\right.$-methyl- $\left.{ }^{11} \mathrm{C}\right]$ cholylsarcosine $\left({ }^{11} \mathrm{C}-\mathrm{CS} a r\right)$. Methods: Six pigs (13 experiments) underwent dynamic ${ }^{11} \mathrm{C}-\mathrm{CS}$ ar PET of the liver with simultaneous measurements of hepatic blood perfusion and ${ }^{11} \mathrm{C}$-CSar concentrations in arterial, portal, and hepatic venous blood. In 3 pigs (7 experiments), bile was collected from a catheter in the common hepatic duct. PET data were analyzed with a 2-tissue compartmental model with calculation of rate constants for the transport of ${ }^{11} \mathrm{C}$-CSar among blood, hepatocytes, and intra- and extrahepatic bile ducts. PET results were validated against invasive blood and bile measurements. Results: The directly measured rate of secretion of ${ }^{11} \mathrm{C}-\mathrm{CS} a r$ into bile was equal to the rate of removal from blood at steady state. Accordingly, hepatocytes did not accumulate bile acids but simply facilitated the transport of bile acids from blood to bile against a measured concentration gradient of 4,000 . The rate constant for the secretion of ${ }^{11} \mathrm{C}$-CSar from hepatocytes into bile in experiments with a catheter in the common hepatic duct was $25 \%$ of that in experiments without a catheter $(P<0.05)$; we interpreted this result to be mild cholestasis caused by the catheter. The catheter caused an increased backflux of ${ }^{11} \mathrm{C}-\mathrm{CS}$ ar from hepatocytes to blood, and hepatic blood flow was $25 \%$ higher than in experiments without the catheter. The capacity for the overall transport of ${ }^{11} \mathrm{C}$-CSar from blood to bile, as quantified by intrinsic clearance, was significantly lower in experiments with the catheter than in those without the catheter $(P<0.001)$. PET and blood measurements correlated significantly $(P<0.05)$. Conclusion: The in vivo kinetics of hepatobiliary secretion of conjugated bile acids can now be determined by dynamic ${ }^{11} \mathrm{C}-\mathrm{CS}$ ar PET.

Key Words: hepatic excretory function; in vivo liver kinetics; bile salt export pump; intrahepatic cholestasis; functional molecular imaging

J Nucl Med 2016; 57:961-966

DOI: 10.2967/jnumed.115.171579

C onjugated bile acids, the major constituents of bile, are essential for efficient intestinal absorption of dietary lipids, including

Received Dec. 21, 2015; revision accepted Jan. 29, 2016.

For correspondence or reprints contact: Michael Sørensen, Department of Hepatology and Gastroenterology, Aarhus University Hospital, Noerrebrogade 44, Bygn 10, Aarhus, Denmark 8000.

E-mail: michsoer@rm.dk.

Published online Mar. 10, 2016.

COPYRIGHT (C 2016 by the Society of Nuclear Medicine and Molecular Imaging, Inc. lipophilic vitamins and drugs (1-3). The major part of the bile acid pool in humans circulates enterohepatically, and hepatic de novo synthesis constitutes only about $5 \%$ of bile acid secretion (1-3). Hepatocellular uptake of conjugated bile acids from sinusoidal blood is primarily mediated by the $\mathrm{Na}^{+}$-taurocholate-cotransporting polypeptide (NTCP; SLC10A1) and canalicular secretion from hepatocytes into bile by the bile salt export pump (BSEP; ABCB11) (3-6). BSEP is impaired in several cholestatic disorders, such as progressive familial intrahepatic cholestasis type 2, drug-induced cholestasis, primary biliary cholangitis, and primary sclerosing cholangitis; all of these conditions may lead to the accumulation of toxic levels of bile acids in hepatocytes (3-6). However, studying hepatobiliary uptake and secretion of bile acids in vivo is difficult. Isotopically labeled bile acids have been used to study bile acid uptake and secretion in the isolated perfused rat liver $(7,8)$ and conscious dogs $(9)$, and sandwich cultures have been used in attempts to predict the in vivo kinetics of bile acid turnover (10-12). Clinical methods, such as ${ }^{99 \mathrm{~m} T \mathrm{Tc}-m e b r o f e n i n ~ S P E C T ~(13) ~}$ and novel PET tracers for hepatic drug transporters (14), have been used to assess different aspects of hepatic excretory function but not specific bile acid transporters.

The radiolabeled conjugated bile acid analog $\left[N\right.$-methyl- $\left.{ }^{11} \mathrm{C}\right]$ cholylsarcosine $\left({ }^{11} \mathrm{C}\right.$-CSar $)$ is a novel tracer for PET of hepatobiliary secretion (15). Proof-of-concept studies in pigs validated that ${ }^{11} \mathrm{C}$-CSar is secreted into bile and circulates enterohepatically without being metabolized; these properties simplified the analysis of PET data by reducing the number of compartments $(14,16)$. The purpose of the present pig study was to determine the in vivo kinetics of hepatobiliary secretion of ${ }^{11} \mathrm{C}$-CSar by dynamic PET of the liver for the quantification of individual transport steps and bile flow. The findings were validated against invasive blood and bile measurements.

\section{MATERIALS AND METHODS}

\section{Experimental Setup}

Six anesthetized pigs (3-4 mo old, female, Danish Landrace and Yorkshire crossbreed; body weight, 39-42 kg) underwent 1-3 successive PET experiments (13 experiments in total) with ${ }^{11} \mathrm{C}$-CSar administered as a continuous intravenous infusion initiated by a priming bolus. At least 6 radioactive half-lives (i.e., $2 \mathrm{~h}$ ) were allowed to pass between successive ${ }^{11} \mathrm{C}$-CSar administrations. During the PET recording, blood was collected from a femoral artery, the portal vein, and a hepatic vein for measurements of the concentrations of ${ }^{11} \mathrm{C}-\mathrm{CS} a r$ in blood. Hepatic blood flow was measured continuously, and in 3 pigs (7 experiments), bile was collected for measurements of the bile flow rate and biliary concentrations of ${ }^{11} \mathrm{C}-\mathrm{CS}$ ar. 
The study was approved by the Danish Animal Experiments Inspectorate and performed in accordance with the Danish Animal Experimentation Act and European conventions for the protection of vertebrate animals used for experimental and other purposes.

\section{Animal Preparation}

Animals were sedated with an intramuscular injection of midazolam and $S$-ketamine; anesthetized with an infusion of midazolam, $S$-ketamine, and propofol; mechanically ventilated; and kept physiologically stable (17).

For intravenous infusions, Avanti catheters (Cordis) were inserted into the femoral veins. For blood sampling, an Avanti catheter was placed in a femoral artery, and a Cournand 6F catheter (Cook) was placed in a hepatic vein via the right jugular vein. The liver was accessed through a 30-cm-long subcostal incision below the right curvature, and a $5.3 \mathrm{~F}$ catheter (Cook) was inserted directly into the portal vein for blood sampling. Ultrasound transit-time flow meter probes (VeriQ; Medistim) were placed around the portal vein and hepatic arteries for continuous recording of blood flow rates. In 3 pigs, a modified Silkolatex Kehr T-tube catheter (Willy Rusch GmbH) was placed directly in the common hepatic duct (CHD) for the collection of bile.

Total hepatic blood flow rate, $F_{\text {blood }}(\mathrm{mL}$ blood/min), was calculated as $F_{\mathrm{HA}}+F_{\mathrm{PV}}$, where $F_{\mathrm{HA}}$ is the hepatic arterial blood flow rate $(\mathrm{mL}$ blood $/ \mathrm{min})$ and $F_{\mathrm{PV}}$ is the blood flow rate in the portal vein $(\mathrm{mL}$ blood/min). $F_{\text {blood }}$ deviated less than $5 \%$ from the mean value during each PET experiment, and individual mean values of $F_{\text {blood }}$ were used.

After the last experiment, the pigs were given an overdose of phenobarbital (4 g), and the liver was removed and weighed. The liver volume, $V_{\text {liver }}(\mathrm{mL}$ liver tissue), was calculated with a liver density of $1.07 \mathrm{~g} / \mathrm{mL}$ liver tissue (18) and used to calculate hepatic blood perfusion, $Q\left(\mathrm{~mL}\right.$ blood $/ \mathrm{min} / \mathrm{mL}$ liver tissue), as $F_{\text {blood }} / V_{\text {liver }}$.

\section{PET Recording}

Pigs were placed in the supine position in a Biograph 64 Truepoint PET/CT camera (Siemens AG). A topogram of the upper abdomen was used to position the liver and bile ducts within the 21.6-cm transaxial field of view, and a low-dose CT scan (50 mAs [effective] with CAREDose 4D [Siemens]; $120 \mathrm{kV}$; pitch, 0.8; slice thickness, $5 \mathrm{~mm}$ ) was used for attenuation correction of PET emission data and anatomy. ${ }^{11} \mathrm{C}-\mathrm{CS}$ ar was produced as described elsewhere (15) and administered intravenously as a priming bolus of $100 \mathrm{MBq}$ (range, $50-145 \mathrm{MBq}$ ) during the initial 20-25 s of the dynamic 60-min PET recording (list mode) and then as a continuous infusion of $7.2 \mathrm{MBq} / \mathrm{min}$ (range, $4.0-10.5 \mathrm{MBq} / \mathrm{min}$ ). PET data were reconstructed by use of attenuation-weighted ordered-subset expectation maximization with resolution recovery, a $336 \times 336$ matrix, a voxel size of $2 \times 2 \times 2 \mathrm{~mm}$, 4 iterations, 21 subsets, a $2-\mathrm{mm}$ gaussian filter, separate prompts/ randoms, and a central spatial resolution of $4.2 \mathrm{~mm}$ (full width at half maximum). The time frame structure was $20 \times 5 \mathrm{~s}, 15 \times 10 \mathrm{~s}, 3 \times$ $30 \mathrm{~s}, 4 \times 1 \mathrm{~min}, 1 \times 3 \mathrm{~min}$, and $10 \times 5 \mathrm{~min}$, and data were corrected for radioactive decay back to the start of the PET recording.

Using fused PET/CT images, we drew regions of interest on adjacent slices of liver tissue, with the exclusion of large blood vessels and bile ducts and with a distance of at least $3 \mathrm{~cm}$ to the gallbladder. The regions of interest were summed to a volume of interest from which the time course for the concentration of ${ }^{11} \mathrm{C}-\mathrm{CS}$ ar in liver tissue, $C_{\text {liver }}(t)\left(\mathrm{kBq} / \mathrm{cm}^{3}\right.$ liver tissue), was generated.

\section{Blood and Bile Samples}

During the PET recording, $0.5-\mathrm{mL}$ blood samples were collected at time points $12 \times 5 \mathrm{~s}, 6 \times 10 \mathrm{~s}, 6 \times 30 \mathrm{~s}, 5 \times 1 \mathrm{~min}$, and $5 \times 10 \mathrm{~min}$ from the femoral artery, portal vein, and hepatic vein for measurements of concentrations of ${ }^{11} \mathrm{C}-\mathrm{CS}$ ar in blood (Packard well counter). Measurements were corrected for radioactive decay back to the start of the PET recording, and time courses for the concentrations of ${ }^{11} \mathrm{C}-\mathrm{CS}$ ar in blood $(\mathrm{kBq} / \mathrm{mL}$ blood) were generated for the hepatic artery, $C_{\mathrm{HA}}(t)$ (identical to that measured in the femoral artery), the portal vein, $C_{\mathrm{PV}}(t)$, and the hepatic vein, $C_{\text {out }}(t)$. The time course for the flow-weighted mixedinlet concentration of ${ }^{11} \mathrm{C}-\mathrm{CS} a r$ in the liver, $C_{\mathrm{in}}(t)(\mathrm{kBq} / \mathrm{mL}$ blood $)$, was calculated (19) as

$$
C_{\mathrm{in}}(t)=f_{\mathrm{HA}} C_{\mathrm{HA}}(t)+\left(1-f_{\mathrm{HA}}\right) C_{\mathrm{PV}}(t),
$$

where $f_{\mathrm{HA}}$ is the arterial flow fraction calculated as $F_{\mathrm{HA}} / F_{\text {blood }}$; it was, on average, 0.26 (range, $0.18-0.39$ ), with no systematic changes during the experiments.

Bile was collected by being allowed to flow continuously from the CHD catheter into test tubes, which were weighed before and after sampling. The bile flow rate, $F_{\text {bile }}(\mathrm{mL}$ bile/min), calculated with a measured bile density of $1.0 \mathrm{~g} / \mathrm{mL}$ bile, deviated less than $5 \%$ from the mean value during each experiment, and individual mean values of $F_{\text {bile }}$ were used. Measured concentrations of ${ }^{11} \mathrm{C}-\mathrm{CS}$ ar in bile $(\mathrm{kBq} / \mathrm{mL}$ bile) were corrected for radioactive decay back to the start of the PET recording and a sampling delay of $6 \mathrm{~min}$, yielding time courses for the concentrations of ${ }^{11} \mathrm{C}-\mathrm{CS}$ ar in bile, $C_{\mathrm{bile}}(t)$.

\section{Calculations from PET Measurements}

PET data were analyzed by fitting the kinetic model of hepatobiliary uptake and secretion (Fig. 1) to the data. The equations for this model are

$$
\begin{array}{ccc}
C_{\text {liver }}(t)=V_{\text {blood }} C_{\text {in }}(t)+C_{\text {hep }}(t)+C_{\text {bile }}(t), & \text { Eq. 2a } \\
d C_{\text {hep }}(t) / d t=K_{\text {mem }} C_{\text {in }}(t)-\left(k_{\text {backflux }}+k_{\text {BSEP }}\right) C_{\text {hep }}(t), & & \text { Eq. } 2 \mathrm{~b} \\
d C_{\text {bile }}(t) / d t=k_{\text {BSEP }}(t) C_{\text {hep }}(t)-k_{\text {bile }} C_{\text {bile }}(t) . & \text { Eq. } 2 \mathrm{c}
\end{array}
$$

The model parameters $K_{\text {mem }}, k_{\text {backflux }}, k_{\mathrm{BSEP}}$, and $k_{\text {bile }}$ were estimated by nonlinear least-squares minimization with software designed inhouse (www.liver.dk/ifit.html) and with $C_{\text {liver }}(t)$ as the output, $C_{\text {in }}(t)$ as the input, and $V_{\text {blood }}$ set to $0.2 \mathrm{~mL}$ blood $/ \mathrm{cm}^{3}$ liver tissue. $C_{\text {bile }}(t)$ was measured in experiments with the CHD catheter but was not used to estimate the model parameters.

The hepatic systemic clearance of ${ }^{11} \mathrm{C}-\mathrm{CSar}, K_{\text {sys }}(\mathrm{mL}$ blood $/ \mathrm{min} /$ $\mathrm{mL}$ liver tissue), was calculated (20) as

$$
K_{\mathrm{sys}}=K_{\mathrm{mem}} k_{\mathrm{BSEP}} /\left(k_{\text {backflux }}+k_{\mathrm{BSEP}}\right) .
$$

In some cases, the analysis yielded $K_{\text {mem }}$ values higher than $Q$, an innate problem with compartmental analysis of PET data (21); in these cases, $K_{\text {mem }}$ was calculated as $Q E_{0}$ (unidirectional extraction fraction) in Equation 3 (22).

The hepatic intrinsic clearance of ${ }^{11} \mathrm{C}-\mathrm{CSar}, K_{\text {int }}(\mathrm{mL}$ blood $/ \mathrm{min} /$ $\mathrm{mL}$ liver tissue), which is not dependent on flow, was calculated (23) as

$$
K_{\mathrm{int}}=-Q \ln \left(1-K_{\mathrm{sys}} / Q\right)
$$

\section{Calculations from Blood and Bile Measurements}

The time course for the hepatic extraction fraction of ${ }^{11} \mathrm{C}-\mathrm{CSar}$ from blood, $E(t)$, was calculated as

$$
E(t)=\left(C_{\text {in }}(t)-C_{\text {out }}(t)\right) / C_{\text {in }}(t) .
$$

Data from the first minute, when backflux can be ignored (24), were used to calculate the unidirectional extraction fraction of ${ }^{11} \mathrm{C}-\mathrm{CS}$ ar, $E_{0}$, from blood to hepatocytes across the hepatocyte sinusoidal membrane; to 


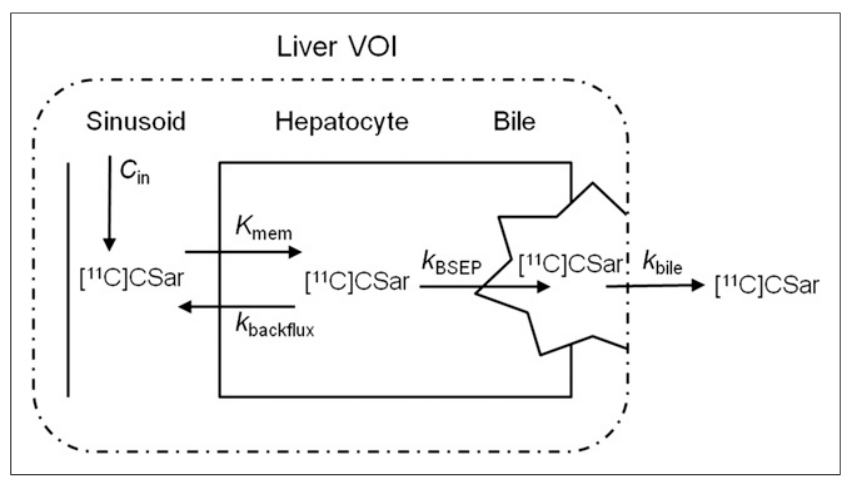

FIGURE 1. Kinetic model fitted to PET data. Liver VOI comprises 3 separate compartments: blood, hepatocytes, and intrahepatic bile volume. Exchange of ${ }^{11} \mathrm{C}$-CSar among compartments is described by unidirectional removal of ${ }^{11} \mathrm{C}$-CSar from blood to hepatocytes by clearance $K_{\text {mem }}(\mathrm{mL}$ blood $/ \mathrm{min} / \mathrm{mL}$ liver tissue), backflux of tracer from hepatocytes to blood by rate constant $k_{\text {backflux }}\left(\mathrm{min}^{-1}\right)$, secretion from hepatocytes into bile canaliculi via BSEP by rate constant $k_{\text {BSEP }}\left(\mathrm{min}^{-1}\right)$, and ${ }^{11} \mathrm{C}$-CSar in bile flowing out of liver volume of interest by rate constant $k_{\text {bile }}\left(\min ^{-1}\right)$.

adjust for non-steady state, $C_{\text {out }}$ was corrected for a mean transit time of 23 s. Steady-state blood concentrations of $C_{\text {in }}$ and $C_{\text {out }}$ at $40-50 \mathrm{~min}$ were used to calculate the hepatic steady-state extraction fraction of ${ }^{11} \mathrm{C}-\mathrm{CS} a r, E_{\mathrm{ss}}$.

The non-flow-dependent permeability-surface area product, $P S_{\mathrm{mem}}$ ( $\mathrm{mL}$ blood $/ \mathrm{min} / \mathrm{mL}$ liver tissue), which is the unidirectional intrinsic clearance of the hepatocyte sinusoidal membrane for ${ }^{11} \mathrm{C}$-CSar, was calculated (24) as

$$
P S_{\mathrm{mem}}=-Q \ln \left(1-\mathrm{E}_{0}\right)
$$

The steady-state hepatic rate of removal of ${ }^{11} \mathrm{C}$-CSar from blood, $v_{\mathrm{ss}}(\mathrm{kBq} / \mathrm{min})$, was calculated for the whole liver as

$$
v_{\mathrm{ss}}=F_{\text {blood }}\left(C_{\text {in }}-C_{\text {out }}\right) .
$$

The non-flow-dependent hepatic intrinsic clearance of ${ }^{11} \mathrm{C}$-CSar from blood into bile, $C l_{\text {int }}(\mathrm{mL}$ blood $/ \mathrm{min} / \mathrm{mL}$ liver tissue), was calculated $(23,24)$ as

$$
C l_{\text {int }}=-Q \ln \left(1-E_{\mathrm{ss}}\right) .
$$

The flow-dependent hepatic systemic clearance of ${ }^{11} \mathrm{C}-\mathrm{CSar}, \mathrm{Cl}_{\mathrm{sys}}$ ( $\mathrm{mL}$ blood $/ \mathrm{min} / \mathrm{mL}$ liver tissue), was calculated as

$$
C l_{\mathrm{sys}}=Q E_{\mathrm{ss}} \text {. }
$$

The concentration of ${ }^{11} \mathrm{C}-\mathrm{CS}$ ar in bile at $50 \mathrm{~min}$ after the start of the infusion of ${ }^{11} \mathrm{C}-\mathrm{CS} a r, C_{\text {bile }}(\mathrm{kBq} / \mathrm{mL}$ bile), was used to calculate the steady-state rate of secretion of ${ }^{11} \mathrm{C}$-CSar, $v_{\text {bile }}(\mathrm{kBq} / \mathrm{min})$, as

$$
v_{\text {bile }}=F_{\text {bile }} C_{\text {bile }}
$$

The fractional intrahepatic bile volume, $V_{\text {bile }}(\mathrm{mL}$ bile $/ \mathrm{mL}$ liver tissue), was calculated as

$$
V_{\text {bile }}=F_{\text {bile }} /\left(k_{\text {bile }} V_{\text {liver }}\right) .
$$

Using the mean $V_{\text {bile }}$ value from experiments with the CHD catheter and individual values for $k_{\text {bile }}$ and $V_{\text {liver }}$ from each experiment, we calculated $F_{\text {bile }}$ in pig experiments without the CHD catheter as

$$
F_{\text {bile }}=V_{\text {bile }} k_{\text {bile }} V_{\text {liver }} \text {. }
$$

\section{Statistical Analysis}

Data are reported as means and $95 \%$ confidence intervals (CIs) or as means and ranges. Individually measured data were weighted with the inverse squared SEE for the calculation of group mean values. The Student $t$ test was used to test differences between pigs with the CHD catheter and pigs without the CHD catheter; a $P$ value of less than 0.05 was considered to indicate statistical significance.

\section{RESULTS}

Figure 2 shows examples of the time courses for ${ }^{11} \mathrm{C}-\mathrm{CS}$ ar concentrations in blood, liver tissue, and bile in experiments without the catheter in the CHD and experiments with the catheter in the CHD. In all experiments, $C_{\text {in }}(t)$ and $C_{\text {out }}(t)$ became constant after 1020 min. $C_{\text {liver }}(t)$ increased rapidly in all experiments. However, steady levels of $C_{\text {liver }}(t)$ were reached in only half of the experiments with the CHD catheter, whereas steady levels were reached within $20 \mathrm{~min}$ in two-thirds of the experiments without the CHD catheter. These findings are in agreement with a cholestatic effect that was caused by the CHD catheter and that primarily affected hepatocyte secretion of ${ }^{11} \mathrm{C}$-CSar into bile, not uptake from blood. Interestingly, $C_{\text {bile }}(t)$ had the same shape as the corresponding $C_{\text {liver }}(t)$, but the concentration in bile was, on average, 200 times higher (Fig. 2C).

The values of the kinetic parameters estimated from PET data are shown in Table 1 . Mean $k_{\mathrm{BSEP}}$ was many times higher than mean $k_{\text {backflux }}$, illustrating that secretion from hepatocytes into bile was much more efficient and physiologically significant than backflux. The CHD catheter caused a significant decrease in both $k_{\mathrm{BSEP}}$ and $K_{\text {int }}$, an insignificant decrease in $k_{\text {bile, }}$, and a significant increase in $k_{\text {backflux }}$. These data indicate a minor cholestatic effect of the CHD catheter (reduced $\left.k_{\mathrm{bile}}\right)$ that led to reduced secretion from hepatocytes into bile $\left(k_{\mathrm{BSEP}}\right)$ which, in turn, led to increased backflux of ${ }^{11} \mathrm{C}$-CSar from hepatocytes to blood $\left(k_{\text {backflux }}\right)$. In accordance with these findings, $K_{\text {int }}$ was significantly higher in experiments without the CHD catheter than in experiments with the CHD catheter. $K_{\text {sys }}$ was unaffected by the CHD catheter; this result can be explained by an increase in $Q$ (discussed later in article) because $K_{\text {sys }}$ is determined by flow.

Mean steady-state $C_{\text {bile }}$ was $22,000 \mathrm{kBq} / \mathrm{mL}$ bile (range, $8,000-38,000 \mathrm{kBq} / \mathrm{mL}$ bile); this value was, on average, 4,000 times (range, 2,400-4,700 times) higher than the corresponding $C_{\text {in. }}$. Mean measured $F_{\text {bile }}$ was $0.27 \mathrm{~mL}$ bile/min $(95 \% \mathrm{CI}, 0.21-0.33 \mathrm{~mL}$ bile/min). The fractional intrahepatic bile volume, $V_{\text {bile, }}$, was, on average, $2.1 \mathrm{~mL}$ bile/L liver tissue (range, 1.21-7.52 mL bile/L liver tissue). In studies without the CHD catheter, calculated $F_{\text {bile }}$ was, on average, $0.45 \mathrm{~mL}$ bile/min (range, $0.37-0.52 \mathrm{~mL}$ bile $/ \mathrm{min})(P<$ 0.05 in comparison with measured values in experiments with the CHD catheter).

Values for hepatic blood perfusion and kinetic parameters for hepatic uptake from blood and biliary secretion of ${ }^{11} \mathrm{C}-\mathrm{CSar}$ calculated from blood measurements are shown in Table 2. Interestingly, $Q$ was, on average, $25 \%$ higher in experiments with the CHD catheter than in experiments without the CHD catheter $(P<0.05)$; this result was caused by an increase in portal vein blood flow with no change in hepatic arterial blood flow.

$E_{0}$ was lower in experiments with the CHD catheter than in experiments without the CHD catheter but was still close to unity; 


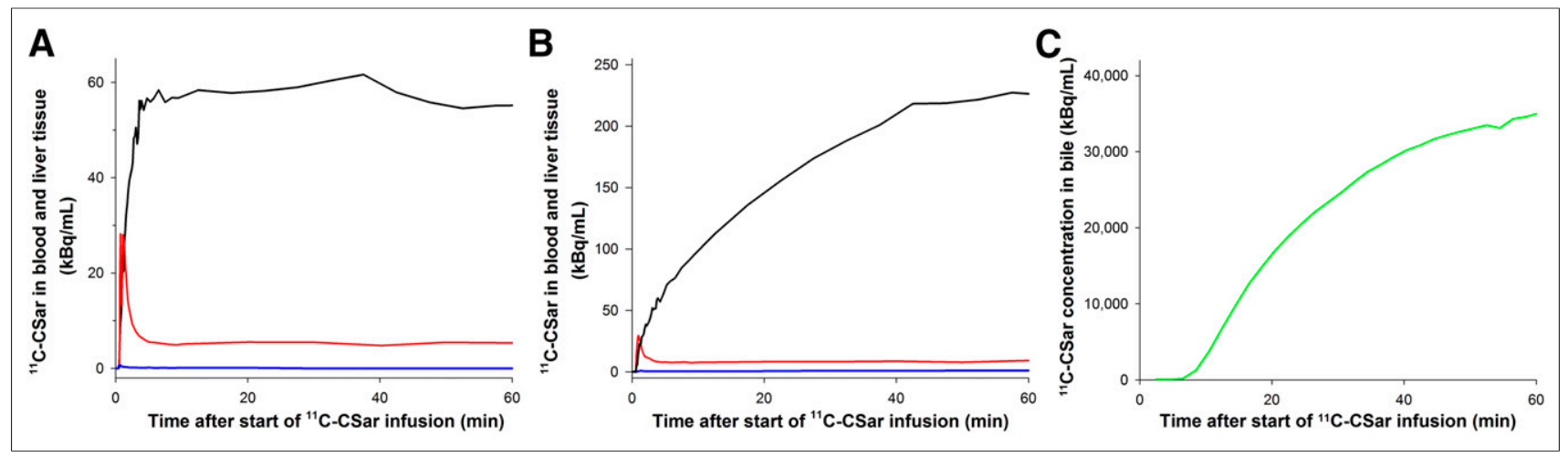

FIGURE 2. (A and B) Time courses of ${ }^{11} \mathrm{C}$-CSar concentrations in flow-weighted mixed-inlet blood ( $C_{\text {in }}$; red), hepatic venous blood $\left(C_{\text {out }}\right.$; blue), and liver tissue ( $C_{\text {liver }}$; black) in experiment without catheter in $\mathrm{CHD}(\mathrm{A})$ and experiment with catheter in $\mathrm{CHD}(\mathrm{B})$. (C) Time course of ${ }^{11} \mathrm{C}-\mathrm{CS} a r$ concentration in bile samples ( $C_{\text {bile }}$; green) in same experiment as in $\mathrm{B}$.

this result indicates high unidirectional transport of ${ }^{11} \mathrm{C}-\mathrm{CS}$ ar from blood to hepatocytes in both groups of animals. Because $E_{0}$ is dependent on flow, the small but statistically significant difference between $E_{0}$ in the 2 groups of animals can be explained by the difference in $Q(22,23)$ - an explanation confirmed by the unaffected, non-flow-dependent $P S_{\text {mem }}$ values. Accordingly, the transport capacity for ${ }^{11} \mathrm{C}-\mathrm{CS}$ ar across the hepatocyte sinusoidal membrane was unaffected by the CHD catheter.

The capacity for the overall transport of ${ }^{11} \mathrm{C}-\mathrm{CS}$ ar from blood to bile, as quantified by the intrinsic clearance, $C l_{\text {int }}$ (Table 2), was significantly lower in pigs with the CHD catheter than in pigs without the CHD catheter $(P<0.001)$. Furthermore, $E_{\mathrm{ss}}$ was significantly lower than $E_{0}$ in pigs with the CHD catheter $(P<$ $0.05)$, whereas it was not statistically different from $E_{0}$ in experiments without the CHD catheter (Table 2). These results show that the reduced secretion of ${ }^{11} \mathrm{C}$-CSar in experiments with the $\mathrm{CHD}$ catheter caused an increased backflux of ${ }^{11} \mathrm{C}$-CSar from hepatocytes to blood-as also seen for the PET parameters.

The correlation between $C l_{\text {sys }}$ from blood data and $K_{\text {sys }}$ from PET data and the correlation between $C l_{\text {int }}$ and $K_{\text {int }}$ were both excellent $\left(r^{2}, 0.7 ; P<0.05\right)$.

\section{DISCUSSION}

The main result of the present study is that it is now possible to quantify the individual steps in hepatic uptake and biliary secretion of conjugated bile acids in vivo with dynamic ${ }^{11} \mathrm{C}-\mathrm{CS}$ ar PET. The method was even able to quantify changes in kinetic parameters caused by the acute, albeit mild, cholestasis induced by the CHD catheter. The finding that the steady-state rate of secretion of ${ }^{11} \mathrm{C}$-CSar was equal to the rate of removal from blood (Fig. 3) shows that hepatocytes did not accumulate ${ }^{11} \mathrm{C}$-CSar during the infusion of ${ }^{11} \mathrm{C}-\mathrm{CS}$ ar but simply facilitated the transport of bile acids from blood to bile against a measured concentration gradient of 4,000 .

The steady-state extraction fraction of ${ }^{11} \mathrm{C}$-CSar from blood, $E_{\text {ss }}$, was lower than $E_{0}$ in experiments with the CHD catheter but not in experiments without the CHD catheter. The cholestatic effect of the catheter thus increased the backflux of bile acids from hepatocytes to blood; this effect was not measurable from blood data under normal conditions but was measurable by PET in all experiments. From in vitro studies, it is known that hepatocytes have transporters (MRP3/4 and OST $\alpha / \beta$ ) for the efflux of bile acids to blood; these can be induced during cholestasis $(25,26)$. Therefore, backflux is an innate ability of hepatocytes. Using ${ }^{11} \mathrm{C}$-CSar PET, we demonstrated backflux even in the normal state, not just during cholestasis. Because hepatic blood perfusion was constant throughout each PET recording, the $E_{\mathrm{ss}} / E_{0}$ ratio was equal to $k_{\mathrm{BSEP}} /\left(k_{\text {backflux }}+k_{\mathrm{BSEP}}\right)$ (22). This relationship shows that the physiologic significance of backflux is relative to canalicular secretion and that a decrease in $k_{\mathrm{BSEP}}$ can cause an apparent increase

TABLE 1

Hepatobiliary Secretion Kinetics Calculated for ${ }^{11} \mathrm{C}-\mathrm{CS}$ ar from PET Measurements

\begin{tabular}{|c|c|c|c|c|c|c|c|c|c|c|}
\hline \multirow[b]{2}{*}{ Pigs } & \multicolumn{2}{|c|}{$k_{\text {backflux }} \min ^{-1}$} & \multicolumn{2}{|c|}{$k_{\mathrm{BSEP}} \mathrm{min}^{-1}$} & \multicolumn{2}{|c|}{$k_{\text {bile }} \min ^{-1}$} & \multicolumn{2}{|c|}{$\begin{array}{c}K_{\text {int }}(\mathrm{mL} \text { blood/ } \\
\mathrm{min} / \mathrm{mL} \text { liver tissue })\end{array}$} & \multicolumn{2}{|c|}{$\begin{array}{c}K_{\text {sys }}(\mathrm{mL} \text { blood/ } \\
\mathrm{min} / \mathrm{mL} \text { liver tissue) }\end{array}$} \\
\hline & $\begin{array}{l}\text { Weighted } \\
\text { mean }\end{array}$ & $95 \% \mathrm{Cl}$ & $\begin{array}{l}\text { Weighted } \\
\text { mean }\end{array}$ & $95 \% \mathrm{Cl}$ & $\begin{array}{l}\text { Weighted } \\
\text { mean }\end{array}$ & $95 \% \mathrm{Cl}$ & $\begin{array}{l}\text { Weighted } \\
\text { mean }\end{array}$ & $95 \% \mathrm{Cl}$ & $\begin{array}{l}\text { Weighted } \\
\text { mean }\end{array}$ & $95 \% \mathrm{Cl}$ \\
\hline $\begin{array}{l}\text { Without CHD } \\
\text { catheter }\end{array}$ & 0.001 & $\begin{array}{c}0.0008 \text { to } \\
0.0012\end{array}$ & 0.18 & 0.15 to 0.21 & 0.21 & $\begin{array}{c}0.17 \text { to } \\
0.24\end{array}$ & 3.32 & $\begin{array}{c}3.01 \text { to } \\
3.63\end{array}$ & 0.81 & $\begin{array}{c}0.74 \text { to } \\
0.88\end{array}$ \\
\hline $\begin{array}{l}\text { With CHD } \\
\text { catheter }\end{array}$ & $0.028^{*}$ & $\begin{array}{c}0.005 \text { to } \\
0.050\end{array}$ & $0.04^{*}$ & -0.01 to 0.08 & 0.09 & $\begin{array}{c}0.04 \text { to } \\
0.14\end{array}$ & $0.65^{\star}$ & $\begin{array}{c}-0.27 \text { to } \\
1.57\end{array}$ & 0.49 & $\begin{array}{c}0.095 \text { to } \\
0.893\end{array}$ \\
\hline
\end{tabular}

${ }^{\star} P<0.05$ for comparison with data from pigs without $\mathrm{CHD}$ catheter. 
TABLE 2

Hepatobiliary Secretion Kinetics Calculated for ${ }^{11} \mathrm{C}-\mathrm{CS}$ ar from Blood Measurements

\begin{tabular}{|c|c|c|c|c|c|c|c|c|c|c|c|c|}
\hline \multirow[b]{2}{*}{ Pigs } & \multicolumn{2}{|c|}{$\begin{array}{c}Q(\mathrm{~mL} \text { blood/ } \\
\mathrm{min} / \mathrm{mL} \text { liver tissue) }\end{array}$} & \multicolumn{2}{|c|}{$E_{0}$} & \multicolumn{2}{|c|}{$\begin{array}{l}P S_{\text {mem }} \text { (mL blood/ } \\
\text { min/mL liver tissue) }\end{array}$} & \multicolumn{2}{|c|}{$E_{\mathrm{ss}}$} & \multicolumn{2}{|c|}{$\begin{array}{c}C l_{\text {int }}(\mathrm{mL} \text { blood/ } \\
\mathrm{min} / \mathrm{mL} \text { liver tissue) }\end{array}$} & \multicolumn{2}{|c|}{$\begin{array}{c}\mathrm{Cl}_{\text {sys }}(\mathrm{mL} \text { blood} / \\
\mathrm{min} / \mathrm{mL} \text { liver tissue) }\end{array}$} \\
\hline & $\begin{array}{l}\text { Weighted } \\
\text { mean }\end{array}$ & $95 \% \mathrm{Cl}$ & $\begin{array}{l}\text { Weighted } \\
\text { mean }\end{array}$ & $95 \% \mathrm{Cl}$ & $\begin{array}{l}\text { Weighted } \\
\text { mean }\end{array}$ & $95 \% \mathrm{Cl}$ & $\begin{array}{l}\text { Weighted } \\
\text { mean }\end{array}$ & $95 \% \mathrm{Cl}$ & $\begin{array}{l}\text { Weighted } \\
\text { mean }\end{array}$ & $95 \% \mathrm{Cl}$ & $\begin{array}{l}\text { Weighted } \\
\text { mean }\end{array}$ & $95 \% \mathrm{Cl}$ \\
\hline $\begin{array}{l}\text { Without CHD } \\
\text { catheter }\end{array}$ & 0.82 & $\begin{array}{r}0.76 \text { to } \\
0.88\end{array}$ & 0.99 & $\begin{array}{r}0.988 \text { to } \\
0.992\end{array}$ & 3.63 & $\begin{array}{r}3.15 \text { to } \\
4.12\end{array}$ & 0.97 & $\begin{array}{r}0.94 \text { to } \\
0.99\end{array}$ & 2.79 & $\begin{array}{r}1.95 \text { to } \\
3.63\end{array}$ & 0.79 & $\begin{array}{r}0.71 \text { to } \\
0.86\end{array}$ \\
\hline $\begin{array}{l}\text { With CHD } \\
\text { catheter }\end{array}$ & $1.01^{\star}$ & $\begin{array}{r}0.90 \text { to } \\
1.11\end{array}$ & $0.96^{\dagger}$ & $\begin{array}{r}0.958 \text { to } \\
0.963\end{array}$ & 3.53 & $\begin{array}{r}2.98 \text { to } \\
4.09\end{array}$ & $0.79^{\dagger}$ & $\begin{array}{r}0.59 \text { to } \\
0.99\end{array}$ & $1.70^{\ddagger}$ & $\begin{array}{r}0.73 \text { to } \\
2.66\end{array}$ & 0.81 & $\begin{array}{r}0.60 \text { to } \\
1.02\end{array}$ \\
\hline
\end{tabular}

in $k_{\text {backflux }}(22)$. Using dynamic ${ }^{11} \mathrm{C}$-CSar PET, we showed that $k_{\text {backflux }}$ in acute cholestasis was, in fact, increased-not only relative to $k_{\mathrm{BSEP}}$ but, on average, 20-fold compared with $k_{\text {backflux }}$ in pigs without the CHD catheter. This separation of the individual impacts of $k_{\text {backflux }}$ and $k_{\mathrm{BSEP}}$ on $E_{\mathrm{ss}}$ cannot be determined from blood measurements alone.

Another interesting finding is that the CHD catheter caused a significant increase in hepatic blood perfusion through a selective increase in portal vein blood flow. Because the hepatic systemic clearance of ${ }^{11} \mathrm{C}$-CSar is determined by flow, this increase in portal vein blood flow may serve as a regulatory mechanism to secure high clearance of conjugated bile acids despite impaired BSEP - a theory supported by the finding of similar estimates of hepatic systemic clearance from blood data $\left(\mathrm{Cl}_{\text {sys }}\right)$ and PET data

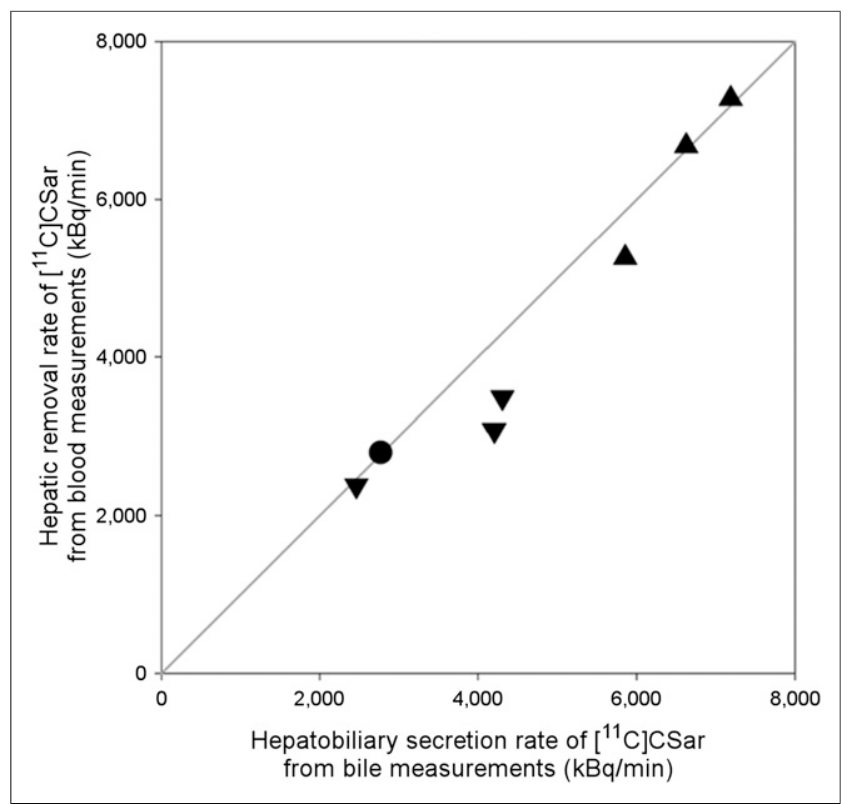

FIGURE 3. Relationship between steady-state hepatic rate of removal of ${ }^{11} \mathrm{C}$-CSar, $v_{\mathrm{ss}}$ (Eq. 7), calculated from blood measurements, and secretion measured directly from bile sampling, $v_{\text {bile }}$ (Eq. 10), in experiments with catheter in CHD. Line of identity is shown. Identical symbols represent repeated measurements in same pig.
$\left(K_{\text {sys }}\right)$ in both groups of animals. However, the data from the present study do not allow us to draw any conclusions about the potential mechanism behind this finding.

Because there was no accumulation of ${ }^{11} \mathrm{C}$-CSar in hepatocytes, the highest possible intrahepatic bile volume was estimated as $C_{\text {liver }} / C_{\text {bile, }}$, which yielded a mean maximum volume of $6.0 \mathrm{~mL}$ bile $/ \mathrm{m}^{3}$ liver tissue (95\% CI, 5.8-6.3 mL bile/L liver tissue). This finding, together with a mean of $3.2 \mathrm{~mL}$ bile/L liver tissue in stereology studies of human biopsies (27), supports the validity of the mean fractional intrahepatic bile volume of $2.1 \mathrm{~mL}$ bile/L liver tissue estimated from the PET data in the present study (Eq. 11).

There was no significant difference between steady-state $C_{\mathrm{HA}}(t)$ and steady-state $C_{\mathrm{PV}}(t)$ (mean difference, 3\%; range, $-19 \%$ to $31 \% ; P>0.30$ ), indicating that there was no loss of ${ }^{11} \mathrm{C}-\mathrm{CSar}$ in the prehepatic splanchnic bed. This finding is important for future human studies because it is not possible to obtain blood samples from the portal vein in such studies. $C_{\mathrm{PV}}(t)$ can then be calculated by use of a model of the transfer of the tracer from that measured in an artery to the portal vein by means of a transfer time constant, $\beta(28,29)$ - which was, on average, $13 \mathrm{~s}(95 \% \mathrm{CI}$, 6.0-18.6 s) in the present study. Further development of a completely noninvasive method for human studies may be facilitated if arterial blood sampling can be replaced by an image-derived input function, as for $2-{ }^{18} \mathrm{~F}$-fluoro-2-deoxy-D-galactose (30), and if a method without the present need for hepatic vein catheterization can be developed.

${ }^{11} \mathrm{C}-\mathrm{CS} a r$ was the first conjugated bile acid analog for functional PET studies, but other bile acid tracers, such as $\mathrm{N}^{-11} \mathrm{C}$-methyl-tauroursodeoxycholic acid, have since been produced (31). Clinical applications of PET studies with radiolabeled bile acids are likely to include clinical evaluation of patients with cholestatic disorders that affect bile acid uptake, secretion, or bile flow and evaluation of disease progression or treatment efficacy. This technique can also be used to examine how pharmaceuticals may affect hepatobiliary excretory functions.

\section{CONCLUSION}

Functional ${ }^{11} \mathrm{C}$-CSar PET was successful for quantification of the in vivo kinetics of hepatobiliary secretion of conjugated bile acids by external detection in pigs. 


\section{DISCLOSURE}

The costs of publication of this article were defrayed in part by the payment of page charges. Therefore, and solely to indicate this fact, this article is hereby marked "advertisement" in accordance with 18 USC section 1734 . This work was supported in part by the National Institute of Diabetes and Digestive and Kidney Diseases (R01DK074419), the Danish Council for Independent Research (Medical Sciences, 12-125512), and Helga and Peter Korning's Foundation. No other potential conflict of interest relevant to this article was reported.

\section{ACKNOWLEDGMENT}

We thank Ludvik Bass (Department of Mathematics, University of Queensland, Brisbane, Queensland, Australia) for pivotal discussions on data interpretation.

\section{REFERENCES}

1. Frisch K, Hofmann AF. Biliary secretion. In: Keiding S, Sørensen M, eds. Functional Molecular Imaging in Hepatology. Sharjah, United Arab Emirates: Bentham Science Publishers; 2012:49-75.

2. Hofmann AF. The enterohepatic circulation of bile acids in mammals: form and functions. Front Biosci (Landmark Ed). 2009;14:2584-2598.

3. Kullak-Ublick GA, Stieger B, Meier PJ. Enterohepatic bile salt transporters in normal physiology and liver disease. Gastroenterology. 2004;126:322-342.

4. Padda MS, Sanchez M, Akhtar AJ, Boyer JL. Drug induced cholestasis. Hepatology. 2011;53:1377-1387.

5. Trauner M, Boyer JL. Bile salt transporters: molecular characterization, function, and regulation. Physiol Rev. 2003;83:633-671.

6. Zollner G, Trauner M. Mechanisms of cholestasis. Clin Liver Dis. 2008;12:1-26.

7. Clayton LM, Gurantz D, Hofmann AF, Hagey LR, Schteingart CD. Role of bile acid conjugation in hepatic transport of dihydroxy bile acids. J Pharmacol Exp Ther. 1989;248:1130-1137.

8. Holzinger F, Schteingart CD, Ton-Nu H-T, et al. Transport of fluorescent bile acids by the isolated perfused rat liver: kinetics, sequestration and mobilization. Hepatology. 1998;28:510-520.

9. Pries JM, Sherman CA, Williams GC, Hanson RF. Hepatic extraction of bile salts in conscious dogs. Am J Physiol. 1979;236:E191-E197.

10. Kimoto E, Yoshida K, Balogh LM, et al. Characterization of organic anion transporting polypeptide (OATP) expression and its functional contribution to the uptake of substrates in human hepatocytes. Mol Pharm. 2012;9:3535-3542.

11. Marion TL, Perry CH, St. Claire RL III, Brouwer KL. Endogenous bile acid disposition in rat and human sandwich-cultured hepatocytes. Toxicol Appl Pharmacol. 2012;261:1-9.

12. Nakakariya M, Ono M, Amano N, Moriwaki T, Meada K, Sugiyama Y. In vivo biliary clearance should be predicted by intrinsic biliary clearance in sandwichcultured hepatocytes. Drug Metab Dispos. 2012;40:602-609.

13. de Graaf W, van Lienden KP, van Gulik TM, Bennink RJ. ${ }^{99 m}$ Tc-mebrofenin hepatobiliary scintigraphy with SPECT for the assessment of hepatic function and liver functional volume before partial hepatectomy. J Nucl Med. 2010;51:229-236.
14. Takashima T, Kitamura S, Wada Y, et al. PET imaging-based evaluation of hepatobiliary transport in humans with (15R)- ${ }^{11} \mathrm{C}$-TIC-Me. J Nucl Med. 2012;53: 741-748.

15. Frisch K, Jakobsen S, Sørensen M, et al. $\left[N\right.$-methyl- $\left.{ }^{11} \mathrm{C}\right]$ cholylsarcosine, a novel bile acid tracer for PET/CT of hepatic excretory function: radiosynthesis and proof-of-concept studies in pigs. J Nucl Med. 2012;53:772-778.

16. He J, Yu Y, Prasad B, et al. PET imaging of Oatp-mediated hepatobiliary transport of $\left[{ }^{11}\right.$ C $]$ rosuvastatin in the rat. Mol Pharm. 2014;11:2745-2754.

17. Sørensen M, Munk OL, Mortensen FV, et al. Hepatic uptake and metabolism of galactose can be quantified in vivo by $2-\left[{ }^{18} \mathrm{~F}\right]$ fluoro-2-deoxy-galactose positron emission tomography. Am J Physiol Gastrointest Liver Physiol. 2008;295: G27-G36.

18. Winterdahl M, Munk OL, Sørensen M, Mortensen FV, Keiding S. Hepatic blood perfusion measured by 3-minute dynamic ${ }^{18}$ F-FDG PET in pigs. $J$ Nucl Med. 2011;52:1119-1124.

19. Munk OL, Bass L, Roelsgaard K, Bender D, Hansen SB, Keiding S. Liver kinetics of glucose analogs measured in pigs by PET: importance of dual-input blood sampling. J Nucl Med. 2001;42:795-801.

20. Gjedde A. Calculation of cerebral glucose phosphorylation from brain uptake of glucose analogs in vivo: a re-examination. Brain Res. 1982;257:237-274.

21. Munk OL, Keiding S, Bass L. Combining compartmental and microvascular models in interpreting dynamic PET data. In: Keiding S, Sørensen M, eds. Functional Molecular Imaging in Hepatology. Sharjah, United Arab Emirates: Bentham Science Publishers; 2012:24-31.

22. Sørensen M, Keiding S. New findings on cerebral ammonia uptake in HE using functional ${ }^{13} \mathrm{~N}$-ammonia PET. Metab Brain Dis. 2007;22:277-284.

23. Keiding S. Dynamic aspects of hepatic removal of circulating substances. In: McIntyre N, Benhamou J-P, Bircher J, et al., eds. Oxford Textbook of Clinical Hepatology. Oxford, United Kingdom: Oxford University Press; 1991;78-87.

24. Lassen NA, Crone C. The extraction fraction of a capillary bed to hydrophilic molecules: theoretical considerations regarding the single injection technique with a discussion of the role of diffusion between laminar streams (Taylor's effect). In: Crone C, Lassen NA, eds. Capillary Permeability. Copenhagen, Denmark: Munksgaard; 1970:48-59.

25. Ballatori N, Christian WV, Lee JY, et al. OSTalpha-OSTbeta: a major basolateral bile acid and steroid transporter in human intestinal, renal, and biliary epithelia. Hepatology. 2005;42:1270-1279.

26. Wagner M, Zollner G, Trauner M. New molecular insight into the mechanism of cholestasis. J Hepatol. 2009;51:565-580.

27. Casali AM, Siringo S, Sofia S, et al. Quantitative analysis of intrahepatic bile duct component in normal adult human liver and in primary biliary cirrhosis. Pathol Res Pract. 1994;190:201-206.

28. Munk OL, Keiding S, Bass L. Impulse-response function of splanchnic circulation with model-independent constraints: theory and experimental validation. $\mathrm{Am}$ J Physiol Gastrointest Liver Physiol. 2003;285:G671-G680.

29. Winterdahl M, Keiding S, Sørensen M, Mortensen FV, Alstrup AKO, Munk OL. Tracer input for kinetic modelling of liver physiology determined without sampling portal venous blood in pigs. Eur J Nucl Med Mol Imaging. 2011;38:263-270.

30. Horsager J, Munk OL, Sørensen M. Metabolic liver function measured in vivo by dynamic ${ }^{18} \mathrm{~F}-\mathrm{FDG}$ al PET/CT without arterial blood sampling. EJNMMI Res. 2015;5:32.

31. Schacht AC, Sørensen M, Munk OL, Frisch K. Radiosynthesis of novel $\mathrm{N}^{11} \mathrm{C}-$ methyl-taurine conjugated bile acids and biodistribution studies in pigs by PET/ CT. J Nucl Med. 2016;57:628-633. 